\title{
Evaluation of pharmacognostical variations in eight accession of Curcuma longa L.
}

\author{
Kamran Ashraf ${ }^{1,2,4}$, Mohammad Jameel ${ }^{3}$, Mohd Mujeeb ${ }^{4}$ \\ ${ }^{1}$ Department Pharmacology and Chemistry, Faculty of Pharmacy, Universiti Teknologi MARA, Puncak Alam \\ Campus, Bandar Puncak Alam, Selangor Darul Ehsan, Malaysia, ${ }^{2}$ Atta-Ur-Rahman Institute for Natural \\ Products Discovery, Universiti Teknologi MARA, Puncak Alam Campus, Bandar Puncak Alam, Selangor Darul \\ Ehsan, Malaysia, ${ }^{3}$ Regional Research Institute of Unani Medicine, Central Council for Research in Unani \\ Medicine, Aligarh, Uttar Pradesh, India, ${ }^{4}$ Bioactive Natural Product Laboratory, Faculty of Pharmacy, Jamia \\ Hamdard University, New Delhi, India
}

\begin{abstract}
Introduction: In recent days, usage of medicinal plants as an herbal drug to treat various kinds of ailments has got drastically increased. Conventionally, Curcuma longa (rhizome) is used in the treatment of inflammation, cancer, wound healing, diabetes, asthma, antioxidant, anti-aging, antimicrobial, etc. Materials and Methods: The present study deals with the pharmacognostic and preliminary phytochemical evaluation of different accessions of C. longa (rhizome). The pharmacognostical profiles include organoleptic study, microscopy evaluation of the rhizome, powder microscopy, physiochemical paramters and determination of total phenolic and flavonoid content were carried out. Results and Discussion: Results showed that there are significant pharmacognostical variations in different accessions of turmeric. Conclusions: The result of the present study is useful in establishing the standards for identification, authentication, and evaluation of the plant material and the variations as well.
\end{abstract}

Key words: Curcuma longa, India, Pharmacognosy, turmeric, Zingiberaceae

\section{INTRODUCTION}

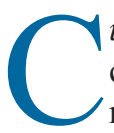
urcuma longa L. (Zingiberaceae) also called turmeric includes $>80$ species of rhizomatous perennial herbs and has extensive presence in the tropics of Asia, Africa, and Australia. ${ }^{[1]}$ It is a perennial herbaceous plant, which ranges a stature of up to $1 \mathrm{~m}$. There are highly branched, yellow-to-orange, cylindrical, and aromatic rhizomes. C. longa is used as a drug in Ayurvedic and Unani system of medicine..$^{[1,2]}$ Others various common name includes Curcuma (Sp. It. Fr.), acafrao da India (port.), geelwortel (Dutch), kurkum (Arab), Manjano (East Africa [KiSwahili]), manjal (Tamil), kunyit (Indonesia), temukunyit (Malaysian), and iyu-chin (Chin.). The chemical components of turmeric are a group of compounds called curcuminoids is a polypohenolic which include curcumin (diferuloylmethane), demethoxycurcumin, and bisdemethoxycurcumin..$^{[3-5]} \quad$ Curcuminoids contain curcumin the principal curcuminoids (about $80 \%$ ), and other two curcuminoids are demethoxycurcumin (about 12\%) and bisdemethoxycurcumin along with other one's protein $(6.3 \%)$, fat $(5.1 \%)$, minerals $(3.5 \%)$, carbohydrates $(69.4 \%)$, and moisture (13.1\%). The essential oil $(5.8 \%)$ obtained by steam distillation of rhizomes has a-phellandrene (1\%), sabinene $(0.6 \%)$, cineol $(1 \%)$, borneol $(0.5 \%)$, zingiberene $(25 \%)$, and sesquiterpenes $(53 \%) .{ }^{[3]}$ The World Health Organization (WHO) has suggested the use of turmeric as a spice. ${ }^{[6]}$ Literature showed that chemical constituents of turmeric are varied according to geographical location, climatic conditions, etc. ${ }^{[1,4]}$ Previous research reported the variation in chemical constituents, as well as molecular diversity of turmeric but very little work has been done on pharmacognostical variations among different accessions of turmeric. Hence, it is imperative to find out the pharmacognostical variation among different accessions of turmeric collected across subcontinent of India.

\section{Address for correspondence: \\ Dr. Mohd Mujeeb, Department of Pharmacognosy and Phytochemistry, Faculty of Pharmacy, Jamia Hamdard University, New Delhi, India. Phone: +91- 9212050090. E-mail: drmmujeeb12@gmail.com}

Received: $05-07-2018$

Revised: $30-07-2018$

Accepted: 06-09-2018 


\section{MATERIALS AND METHODS}

\section{Collection and Authentication of the Drug Samples}

In the present investigation, samples were collected from different geographical regions of India. The fresh rhizomes 8 samples of $C$. longa were collected from various ecological and sub-climatic zones of India during period from October 21, 2011, to January 12, 2012. The collections sites of $C$. longa are given in Table 1. All samples of C. longa were authenticated by taxonomist Professor M.P. Sharma, Department of Botany, Faculty of Science, Jamia Hamdard University. Chemicals and reagents used in the study were purchased from Sigma-Aldrich Corporation, St. Louis, MO USA. All voucher specimens (BNPL/T-12) were deposited in Molecular Ecology Laboratory, Jamia Hamdard, New Delhi, India. Rhizomes were cut into thin sections for microscopy study and also cut into pieces, dried, and powdered for other pharmacognostical study.

\section{Microscopy of Drug Samples}

Transverse section of the fresh rhizome was stained with safranin, mounted with glycerin and was observed under compound microscope. ${ }^{[7]}$

\section{Identification Test}

The individual extract was subjected to the qualitative phytochemical screening for the presence of some chemical constituents. The phytochemical test was carried out adopting standards procedure. ${ }^{[8,9]}$

\section{Physicochemical Evaluation of Drugs}

The physiochemical studies were carried out as per described in the WHO guidelines (WHO, 1991). ${ }^{[10]}$

\section{Determination of Foreign Matter}

The weighed $(100 \mathrm{~g})$ samples were spread out as a thin layer on filter paper. The foreign matter was detected by thrice by inspection with the unaided eye or using a lens $(\times 6)$. All the foreign matter separated from the samples were weighed and calculated as per the percentage present in the samples.

\section{Loss of Drying}

The limit of detection determines the loss of moisture as well as the component present in the particular samples. The powdered drug sample $(1 \mathrm{~g})$ was placed on the tarred evaporating dish of infrared torsion balance moisture meter (Adair DuttKolkatta, India) and dried at $105^{\circ} \mathrm{C}$ for $2 \mathrm{~h}$ and followed by measurements of their reading after every $20 \mathrm{~min}$. The drying was continued till the successive reading coincides with each other, or the difference between two successive reading did not differ by more the $0.25 \%$.

\section{Ash Values}

\section{Total ash}

The ash values were determined according to the method described in pharmacopeia guidelines. To determine the ash value, the powdered drugs $(1.0 \mathrm{~g})$ were incinerated in a silica crucible at a temperature not exceeding $450^{\circ} \mathrm{C}$ until free from carbon. It was then cooled and weighed to get the total ash content. The ash value of samples was calculated.

\section{Acid insoluble ash}

Total ash found was boiled with $25 \mathrm{~mL}$ dilute hydrochloric acid $(6.0 \mathrm{~N})$ for $5 \mathrm{~min}$. The insoluble matter collected on an ashless filter paper washed with hot water and ignited at a temperature not exceeding $450^{\circ} \mathrm{C}$ to a constant weight. After that weight was taken and the acid insoluble ash was calculated.

\section{Water soluble ash}

Water soluble ash was also determined by boiling the ash for $5 \mathrm{~min}$ with $25 \mathrm{~mL}$ of water, collected insoluble matter on ashless filter paper, washed with hot water and ignited for $15 \mathrm{~min}$ at a temperature not exceeding $450^{\circ} \mathrm{C}$. The weight of the insoluble matter was subtracted from the weight of total ash. The difference in weight represents the water-soluble ash.

\begin{tabular}{llcl} 
& \multicolumn{3}{c}{ Table 1: Different accessions of C. longa } \\
Code No. & Cultivation regions(Provinces) & Geographical Co- ordinate & Source \\
T1 & Trivandrum(Kerala) & $8^{\circ} 29^{\prime} 15^{\prime \prime} \mathrm{N}, 76^{\circ} 57^{\prime} 9^{\prime \prime} \mathrm{E}$ & Local farmer \\
$\mathrm{T} 2$ & Lucknow(U.P) & $26^{\circ} 50^{\prime} 49.2^{\prime \prime} \mathrm{N}, 80^{\circ} 56^{\prime} 49.2^{\prime \prime} \mathrm{E}$ & Herbal Garden, Integral University. \\
$\mathrm{T} 3$ & Nashik(Maharashtra) & $20^{\circ} 0^{\prime} \mathrm{O}^{\prime \prime} \mathrm{N}, 73^{\circ} 46^{\prime} 48^{\prime \prime} \mathrm{E}$ & Local farmer \\
$\mathrm{T} 4$ & Delhi (Delhi) & $28^{\circ} 36^{\prime} 36^{\prime \prime} \mathrm{N}, 77^{\circ} 13^{\prime} 48^{\prime \prime} \mathrm{E}$ & Herbal garden, Hamdard University \\
$\mathrm{T} 5$ & Erode (Tamilnadu) & $11^{\circ} 21^{\prime} \mathrm{O}^{\prime \prime} \mathrm{N}, 77^{\circ} 44^{\prime} 0^{\prime \prime} \mathrm{E}$ & Local farmer \\
$\mathrm{T} 6$ & Guwahati (Assam) & $26^{\circ} 11^{\prime} \mathrm{O}^{\prime \prime} \mathrm{N}, 91^{\circ} 44^{\prime} 0^{\prime \prime} \mathrm{E}$ & Local farmer \\
$\mathrm{T} 7$ & Surat (Gujrat) & $26^{\circ} 11^{\prime} 0^{\prime \prime} \mathrm{N}, 91^{\circ} 44^{\prime} 0^{\prime \prime} \mathrm{E}$ & Local farmer \\
$\mathrm{T} 8$ & Patna(Bihar) & $25^{\circ} 36^{\prime} 39.6^{\prime \prime} \mathrm{N}, 85^{\circ} 8^{\prime} 38.4^{\prime \prime} \mathrm{E}$ & Local farmer \\
\hline
\end{tabular}




\section{Determination of Total Phenolic Content}

Determination of total phenolic content in the methanolic extract of all samples were carried out using standard UV spectrophotometric method. ${ }^{[11,12]}$ Gallic acid was used as a standard for the determination of total phenol in all the samples. The total phenolic content was calculated from the calibration curve, and the results were expressed as mg of gallic acid equivalent per $g$ dry weight.

\section{Preparation of Methanolic Extract of $\boldsymbol{C}$. Ionga}

Eight different specimens of $C$. longa rhizomes (each of $1 \mathrm{~g}$ air-dried fresh rhizomes) procured from various locations such as south, west, east, and north of India and were extracted by reflux using $50 \mathrm{~mL}$ of high-performance liquid chromatography grade methanol for minimum of $2 \mathrm{~h}$ at temperature $70^{\circ} \mathrm{C}$ and then filtered through Whatman $\mathrm{No}^{\sharp 42}$. Extracts obtained after the reflux were concentrated on hot water bath and finally, the volume was adjusted to $50 \mathrm{~mL}$ with methanol.

\section{Reagents}

Nearly $10 \%$ the Folin-Ciocalteu(FC) reagent and $\mathrm{Na}_{2} \mathrm{CO}_{3}(1 \mathrm{M})$ were prepared with distilled water and standard (Gallic acid) $1 \mathrm{mg} / \mathrm{mL}$ solution in methanol. Different dilutions were made with methanol from $25 \mu \mathrm{g}$ to $300 \mu \mathrm{g} / \mathrm{mL}$.

\section{Samples Preparation}

About $1 \mathrm{mg} / \mathrm{mL}$ solution of each extract in methanol was prepared followed by withdrawn of $0.5 \mathrm{~L}$ of each one. To this, added $5 \mathrm{~mL} \mathrm{FC}$ reagent and $4 \mathrm{~mL}$ of $\mathrm{Na}_{2} \mathrm{CO}_{3}$ solution and kept for $15 \mathrm{~min}$. Finally, absorbance was taken at $765 \mathrm{~nm}$ of all the samples.

\section{Preparation of Standard}

Different dilutions of the standard reference were prepared in the range of $25-300(\mu \mathrm{g} / \mathrm{mL}) .0 .5 \mathrm{~mL}$ of each standard solution was taken followed by their addition of $5 \mathrm{~mL}$ of FC reagent and $4 \mathrm{~mL}$ of $\mathrm{Na}_{2} \mathrm{CO}_{3}$ solution and kept for $15 \mathrm{~min}$. Absorbance was taken at $765 \mathrm{~nm}$.

\section{Blank Solution}

It was prepared by adding $0.5 \mathrm{ml}$ of methanol to $5 \mathrm{~mL}$ of $\mathrm{FC}$ reagent and $4 \mathrm{~mL} \mathrm{Na}_{2} \mathrm{CO}_{3}$ solution.

\section{Determination of Total Flavonoid Content}

Determination of total flavonoid content in the methanolic extract of all samples were carried out using standard UV spectrophotometric method. ${ }^{[11,12]}$ Rutin was used as a standard for the determination of total flavonoid in all the samples. The total flavonoid content was calculated from a calibration curve, and the results were expressed as mg rutin equivalent per g dry weight.

\section{Preparation of Methanolic Extract}

The same process was adopted as mentioned above for phenolic content.

\section{Reagents}

$\mathrm{AlCl}_{3}(0.1 \mathrm{mg} / \mathrm{mL})$ and $\mathrm{CH}_{3} \mathrm{COONa}(1 \mathrm{M})$ were prepared along with the dilution of Rutin (Standard) from $10 \mu \mathrm{g} / \mathrm{mL}$ to $100 \mu \mathrm{g} / \mathrm{mL}$.

\section{Sample Preparation}

About $1 \mathrm{mg} / \mathrm{mL}$ solution of each extract in methanol was prepared followed by withdrawal of $0.5 \mathrm{~mL}$ of each one. To

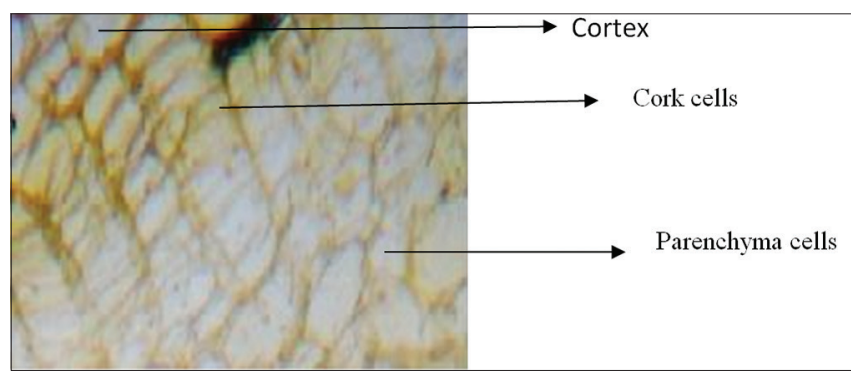

Figure 1: Transverse section of the outer part (one sector) of rhizome of Curcuma longa

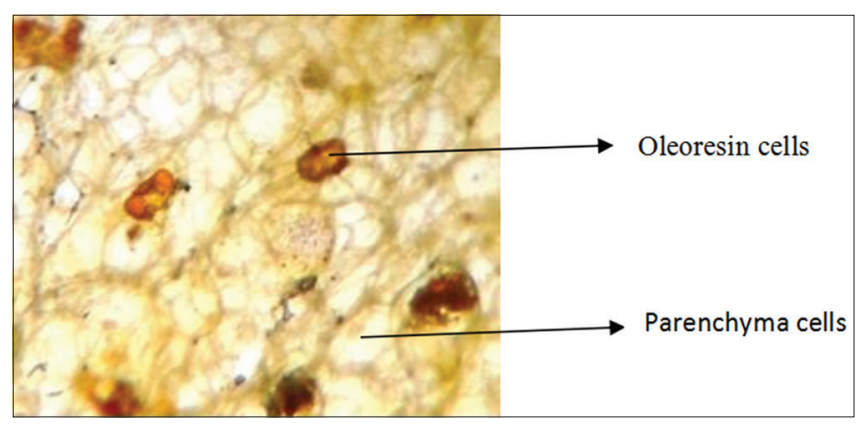

Figure 2: Transverse section of rhizome of Curcuma longa (one-sector)

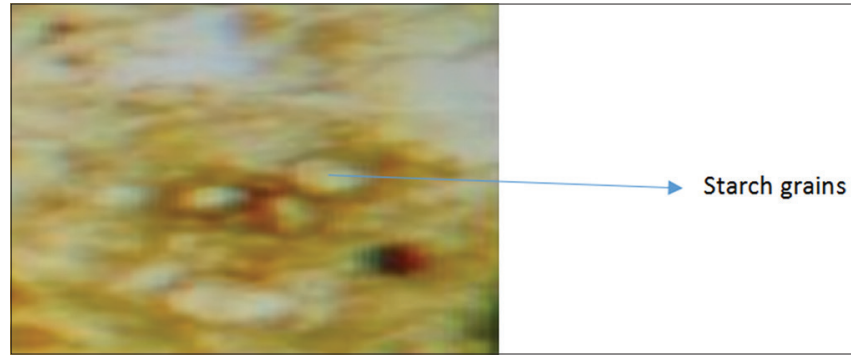

Figure 3: Distribution of starch cells in rhizomes of Curcuma longa 
this, $0.1 \mathrm{~mL} \mathrm{AlCl}$ and $0.1 \mathrm{~mL}$ of $\mathrm{CH}_{3} \mathrm{COONa}$ reagent were added and finally added of $2.8 \mathrm{~mL}$ distilled water and kept for $30 \mathrm{~min}$. The absorbance of all samples were taken at $415 \mathrm{~nm}$.

\section{Preparation of Standard}

Different dilutions of standard reference were prepared in the range of $10-100(\mu \mathrm{g} / \mathrm{mL}) .0 .5 \mathrm{~mL}$ of each standard solution was taken into $1.5 \mathrm{~mL}$ of methanol, then added $0.1 \mathrm{~mL}$ of $\mathrm{AlCl}_{3}, 0.1 \mathrm{~mL}$ of $\mathrm{CH}_{3} \mathrm{COONa}$, and $2.8 \mathrm{~mL}$ of distilled water and kept for $30 \mathrm{~min}$. The absorbance of all samples were taken at $415 \mathrm{~nm}$.

\section{RESULTS AND DISCUSSION}

\section{Microscopic Observation}

Transverse section of the rhizome of turmeric showed the following microscopical characters [Figures 1-3]

a. Epidermis

It is thick-walled having cubical cells of various dimensions.

b. Cortex

These cells are characterized by the presence of mostly thin-walled rounded parenchyma cells.

c. Cork cells

These are composed of 4-6 layers of thin-walled and brick-shaped.

d. Vascular bundles

Vascular bundles are collateral and found to be scattered.

e. Parenchyma cells

These are cells of the ground tissue, and it contains

f. Oil cell starch grains of $4-\mu \mathrm{m}$ in diameter.

It is suberized walls containing orange-yellow globule of volatile oil or amorphous resinous matter.

g. Vessels

Vessels are mainly spirally thickened and having few reticulate and annular structures.

h. Pericycle

It consists of three to four layers of rectangular cells.

i. Vascular tissue

These cells are radially arranged. Phloem patches and xylem are seen to be arranged alternately; j. Pith xylem is found to be in exarch condition.

Well-developed pith is found and is made up of thick-walled parenchymatous cells.

\section{Powder Study of Rhizome of C. longa}

Powder study of the rhizome of $C$. longa showed the following characteristics features:

The powder is brownish black with camphoraceous odor. The taste is bitter; it includes powder fibers and small granules of vessels. Parenchyma cell is spherical to angular cells in the forms of grains. The grains are clumps of the parenchymatous cell. They are filled with starch grains, which become blue with iodine solution. Oleoresin crystals are originally impregnated in the parenchyma, they become free in powder and are found in dispersed condition. Vascular elements large number of vessels elements either entire or in the form of fragments. Vascular elements show spiral and pitted thickenings, most of the elements are of vessel category. Large numbers of fibers are found to be scattered in parenchyma cells.

Phytochemical study results showed that carbohydrate, alkaloid, phenolic, flavonoid, tannin, protein, saponin, mucilage, sterols, anthraquinone and terpenoid were present in all samples of $C$. longa [Table 2].

\section{Table 2: Phytochemical analysis of $C$. longa}

\begin{tabular}{llllllllll} 
S.N & Phytoconstituents & \multicolumn{10}{c}{ Samples } \\
\cline { 2 - 10 } & & T1 & T2 & T3 & T4 & T5 & T6 & T7 & T8 \\
\hline 1 & Carbohydrate & + & + & + & + & + & + & + & + \\
2 & Alkaloid & + & + & + & + & + & + & + & + \\
3 & Anthraquinone & + & + & + & + & + & + & + & + \\
4 & Phenolic and Tannin & + & + & + & + & + & + & + & + \\
5 & Flavonoid & + & + & + & + & + & + & + & + \\
6 & Protein & + & + & + & + & + & + & + & + \\
7 & Saponin & + & + & + & + & + & + & + & + \\
8 & Mucilage & + & + & + & + & + & + & + & + \\
9 & Sterols & + & + & + & + & + & + & + & + \\
10 & Terpenoids & + & + & + & + & + & + & + & + \\
11 & Resins & + & + & + & + & + & + & + & + \\
\hline
\end{tabular}




\begin{tabular}{lcccccc} 
Samples & \multicolumn{2}{c}{ Table 3: Physiochemical data of C. longa } \\
& $\begin{array}{l}\text { Moreign organic } \\
\text { Matter Mean } \pm \text { SD }\end{array}$ & $\begin{array}{c}\text { Total Ash value } \\
\text { Mean } \pm \text { SD }\end{array}$ & $\begin{array}{c}\text { Acid insoluble } \\
\text { value Mean } \pm \text { SD }\end{array}$ & $\begin{array}{c}\text { Alcohol soluble } \\
\text { Extractive value } \\
\text { Mean } \pm \text { SD }\end{array}$ & $\begin{array}{c}\text { Water soluble } \\
\text { Extractive value } \\
\text { Mean } \pm \text { SD }\end{array}$ & $\begin{array}{c}\text { Moisture content } \\
\text { Mean } \pm S D\end{array}$ \\
\hline Delhi & $1.99 \pm 0.095$ & $7.24 \pm 0.511$ & $0.56 \pm 0.017$ & $12.61 \pm 0.600$ & $9.03 \pm 0.846$ & $6.91 \pm 0.262$ \\
Patna & $1.78 \pm 0.023$ & $7.7 \pm 0.318$ & $0.85 \pm 0.028$ & $12.68 \pm 0.400$ & $9.46 \pm 0.622$ & $5.93 \pm 0.491$ \\
Lucknow & $1.3 \pm 0.045$ & $7.43 \pm 0.481$ & $0.533 \pm 0.028$ & $12.80 \pm 0.489$ & $10.56 \pm 0.304$ & $7.43 \pm 0.248$ \\
Erode & $1.97 \pm 0.024$ & $8.0 \pm 0.325$ & $0.466 \pm 0.125$ & $13.70 \pm 0.518$ & $10.73 \pm 0.643$ & $7.56 \pm 0.501$ \\
Trivandrum & $1.78 \pm 2.024$ & $6.8 \pm 0.264$ & $0.433 \pm 0.017$ & $13.02 \pm 0.303$ & $10.21 \pm 0.771$ & $5.0 \pm 0.173$ \\
Surat & $1.92 \pm 0.041$ & $5.0 \pm 0.173$ & $0.566 \pm 0.075$ & $10.63 \pm 0.485$ & $9.63 \pm 0.250$ & $7.7 \pm 0.182$ \\
Nashik & $1.23 \pm 0.032$ & $6.45 \pm 0.217$ & $0.516 \pm 0.076$ & $12.50 \pm 0.687$ & $10.36 \pm 0.198$ & $6.45 \pm 0.217$ \\
Guwahati & $1.57 \pm 0.092$ & $7.56 \pm 0.240$ & $0.55 \pm 0.129$ & $13.52 \pm 0.904$ & $10.6 \pm 0.174$ & $8.16 \pm 0.551$ \\
\hline
\end{tabular}

\begin{tabular}{|c|c|c|c|c|}
\hline Samples & Absorbance (mean+S.D) & Concentrations (mean+S.D) $(\mu \mathrm{g} / \mathrm{mL})$ & $\mathrm{mg} / \mathrm{g} \mathrm{X}=\mathrm{cV} / \mathrm{m}$ & $\%$ w/w \\
\hline Surat & $0.742+0.064$ & $66.25+5.342$ & 66.25 & 6.62 \\
\hline Nashik & $0.767+0.045$ & $69.37+6.843$ & 69.37 & 6.93 \\
\hline Lucknow & $0.965+0.083$ & $94.25+0.456$ & 94.25 & 9.42 \\
\hline Delhi & $1.025+0.984$ & $101.625+10.231$ & 101.625 & 10.16 \\
\hline Trivandrum & $1.161+0.124$ & $118.625+9.674$ & 118.625 & 11.86 \\
\hline Guwahati & $1.223+0.152$ & $126.375+12.562$ & 126.375 & 12.63 \\
\hline Patna & $1.489+0.132$ & $159.625+14.231$ & 159.625 & 15.96 \\
\hline Erode & $1.862+0.127$ & $206.250+17.453$ & 206.250 & 20.62 \\
\hline
\end{tabular}

$\mathrm{X}=\mathrm{cV} / \mathrm{m} \mathrm{X}=$ Total phenol content $\mathrm{c}=$ concentration of gallic acid obtained from calibration curve $\mathrm{m}=$ weight of plant extract $\mathrm{V}=\mathrm{volume}$ used $(\mathrm{mL})$

\begin{tabular}{|c|c|c|c|c|}
\hline Samples & Absorbance (mean+S.D) & Concentrations (mean+S.D) $(\mu \mathrm{g} / \mathrm{mL})$ & $\mathrm{mg} / \mathrm{g} \mathrm{X}=\mathrm{cV} / \mathrm{m}$ & $\%$ w/w \\
\hline Surat & $0.449+0.023$ & $20.83+2.032$ & 20.83 & 2.83 \\
\hline Nashik & $0.528+0.012$ & $34.00+2.045$ & 34.00 & 3.40 \\
\hline Lucknow & $0.621+0.045$ & $49.50+4.183$ & 49.50 & 4.95 \\
\hline Delhi & $0.739+0.076$ & $69.166+5.674$ & 69.166 & 6.91 \\
\hline Trivandrum & $0.614+0.045$ & $48.333+4.124$ & 48.333 & 4.83 \\
\hline Guwahati & $0.695+0.034$ & $61.833+5.785$ & 61.833 & 6.18 \\
\hline Patna & $0.825+0.067$ & $83.500+6.342$ & 83.500 & 8.35 \\
\hline Erode & $0.818+0.089$ & $82.33+4.764$ & 82.33 & 8.23 \\
\hline
\end{tabular}

$\mathrm{X}=\mathrm{cV} / \mathrm{m} \mathrm{X}=$ Total phenol content $\mathrm{c}=$ concentration of gallic acid obtained from calibration curve $\mathrm{m}=$ weight of plant extract $\mathrm{V}=\mathrm{volume}$ used $(\mathrm{mL})$

Physiochemical constant such as foreign organic matter, total ash value, acid insoluble value, alcohol soluble extractive value, water-soluble extractive value, and moisture content of all samples were found to be in the range of I.P. prescribed limit [Table 3]. The total phenolic content of different rhizome samples were quantified using standard UV spectrophotometric method employing gallic acid as standard at $765 \mathrm{~nm}$. The standard calibration curve was found to be linear in the range of $25-300 \mu \mathrm{g} / \mathrm{mL}$ with $\mathrm{r}^{2}=0.995$ and regression equation $y=0.008 x+0.212$ [Table 4]. Data showed that total phenol was found to be highest in a sample collected from Erode $(206.62 \% \mathrm{w} / \mathrm{w})$ followed by Patna $(159.62 \% \mathrm{w} / \mathrm{w})$.
The sample of Surat was reported to contain least phenolic content $(6.62 \% \mathrm{w} / \mathrm{w})$. The results of total flavonoid content of different rhizomes samples were quantified using standard UV spectrophotometric method employing rutin as standard at $415 \mathrm{~nm}$. The standard calibration curve was found to be linear in the range of $10-100 \mu \mathrm{g} / \mathrm{mL}$ with $\mathrm{r}^{2}=0.997$ and regression equation $y=0.006 x+0.324$. Results showed that the Patna contained the highest content of flavonoid $(8.35 \% \mathrm{w} / \mathrm{w})$ whereas lowest content was found in the samples of Surat $(2.83 \% \mathrm{w} / \mathrm{w})$ [Table 5]. C. longa is the valued medicinal plants and possesses broad range of medicinal uses. These plants are distributed mainly in India, Pakistan, and 
Indonesia, etc. Medicines derive exclusively from natural sources and pharmacognostical evaluation of drugs referred to the confirmation of its identity and determination of its quality, purity, and detection of nature of adulterant present in them. The details pharmacognostical account of the plant included macroscopic, microscopic characters for the correct botanical identifications. Histological characters were studied. Microscopy study of turmeric showed epidermis with thick-walled, cubical cells, and cortex cells characterized by the presence of scattered oleo-resin cells with brownish contents. There are no significant variations observed by macroscopical and microscopical evaluation in different accessions of turmeric.

Physiochemical parameters such as determination of foreign organic matters, total ash value, acid insoluble ash value, alcohol extractive value, water extractive value, and moisture content have also been determined to know the quality of drugs. Extractive values are useful for the evaluation, especially when the constituents of the drugs cannot be readily estimated by any other means. It also helps to indicate the nature of chemical constituents present in the drug. ${ }^{[8,13]}$

The water and alcohol extractive values were determined to see the solubility of constituents in their respective solvents, as extractives values were primarily useful for the determinations of exhausted or adulterants drugs. On ignition of crude drugs ash remained, comprises of the cell wall and its content. Ash constitutes the inorganic residues obtained after complete combustion of a drug. It represents the inorganic salts naturally occurring in the drugs and was useful for determining the authenticity of drugs. Thus ash value is a validity parameter describe and to assess the degree of purity of a given drug. Acid insoluble ash limit was imposed specially incase where foreign silica might be present. ${ }^{[14,15]}$ In the case of C. longa the total ash value, alcohol extractive values were found to be highest in the sample of Erode whereas total ash content is lowest in the sample of Surat. The high extractive value may be due to the presence of high fibrous content is this sample. Chemo profiling of herbal drugs is one of the most important tools for quality assessment. The WHO recommended the use of chromatography techniques for the identification and standardization of quality of plant products. As phenolic and flavonoid content are present in turmeric and these are responsible for the antioxidant and anti-inflammatory activities and allowing them to be used as potential chemopreventives. The diversity among accessions of turmeric revealed that phenolic and flavonoid content were varied significantly. Results showed that total phenolic content was highest in a sample of Erode (20.20\% $\mathrm{w} / \mathrm{w})$ whereas Patna contains the highest flavonoid content $(8.35 \% \mathrm{w} / \mathrm{w})$ of C. longa.

Paliwal et al. ${ }^{[16]}$ analyzed phytochemical constituent curcumin and compared it with other samples and found variations among different samples. Paliwal et al. have carried pharmacognostical evaluation in Curcuma caesia and reported distinct features of $C$. caesia. ${ }^{[16]}$ Our results are also confirmatory with the finding of Paliwal. In another experiment, the efficacy of various organic solvents for extracting antioxidant phenolic and flavonoid compounds of turmeric was compared and reported significant variation. ${ }^{[17]}$ Our finding was also supported by this experiment. Phadungcharoen and Theanphong ${ }^{[18]}$ carried out a microscopic investigation of Curcuma petiolata Roxb. rhizome and found several distinct features.

\section{CONCLUSIONS}

Correct identification and purity of plant materials is very important. As per the WHO, the macroscopic and microscopic determination of the drug plants is the first step toward establishing the correct identity and purity of the source materials. Microscopic study of the rhizomes and powdered materials acts as a trustworthy source for detecting adulteration. Genuineness of the powdered materials studied showed that there are resemblances in the anatomical or microscopical features of both fresh and dry, powdered samples of $C$. longa which is the base of assessment to evade adulteration of the drug plants. C. longa is is a potential and functional food ingredients, herbs and natural ingredient for our daily needs. Food supplementation with C. longa may be considered as a novel nutritional approach to reduce chronic diseases as well as mineral deficiency. Experimental data from the literature and as revealed herein indicates adequate information about the use of turmeric as spices with an enormous number of chemical components apart from their several medicinal uses. Large-scale clinical studies are required to rationalize these plants as a suitable phytopharmaceutical drug even though initial data and results from this work seem to be auspicious.

\section{ACKNOWLEDGMENTS}

Kamran Ashraf would like to acknowledge Universiti Teknologi MARA for the financial support under the reference number 600-IRMI/MyRA 5/3/LESTARI (079/2017). Authors would also like to acknowledge University Grants Commission (UGC) Govt. of India for providing research fellowship.

\section{REFERENCES}

1. Ashraf K, Mujeeb M, Ahmad A, Amir M, Mallick NM, Sharma D. Validated HPTLC method analysis for the quantification of curcumin collected from different geographical region of India. Asia. Pac J Trop Biomed 2012;2:S584-8.

2. Ashraf K, Ahmad A, Saa S, Mujeeb M. Genetic diversity in accessions of Indian turmeric (Curcuma longa L.) using 
rapd markers. Int J Pharm Pharm Sci 2017;9:288-91.

3. Ashraf K, Sultan S. Comprehensive review on Curcuma longa Linn: Phytochemical, pharmacological and molecular study: A review. Int J Green Pharm 2017;11:S1.

4. Ashraf K, Mujeeb M, Altaf A, Ahmad N. Determination of curcuminoids in $C$. longa by UPLC- QTOF MS: An application in turmeric cultivation. J Chromat Sci 2015;53:1346-52

5. Maiti K, Mukherjee K, Gaintat A, Saha BP, Mukherjee PK. Curcumin- phospholipid complex: Preparation, therapeutic evaluation and pharmacokinetics study in rats. Int J Pharm 2007;330:155-63.

6. WHO. Quality Control Methods for Medicinal Plant Materials. Geneva: WHO; 2002.

7. Khandelwal KR. Practical Pharmacognosy: Techiques and Experiments. 13 ${ }^{\text {th }}$ ed. Pune: Nirali Prakashan; 2005. p. $149-56$.

8. Evans WC. Trease and Evans Pharmacognosy. $15^{\text {th }}$ ed. Edinburg: W.B. Saunders Publications; 2002.

9. Kokate CK, Purohit AP, Gokhale SB. Pharmacognosy. $23^{\text {rd }}$ ed. Pune: Nirali Prakashan; 1998. p. 106-14.

10. World Health Organization. Programme on Traditional Medicine. Guidelines for the Assessment of Herbal Medicines. Geneva: World Health Organization; 1991.

11. Pourmorad F, Hosseinimehr SJ, Shahabimajd N.
Antioxidant activity, phenol and flavonoid contents of some selected Iranian medicinal plants. Afr J Biotechnol 2006;5:1142-5.

12. Amir M, Mujeeb M, Khan A, Ashraf K, Sharma D, Aqil M. Phytochemical analysis and in vitro antioxidant activity of Uncaria gambir. Int J Green Pharm 2012;6:67-72.

13. Wallis TE. Textbook of Pharmacognosy. $5^{\text {th }}$ ed. New Delhi: CBS Publications; 1985. P. 104-5.

14. WHO. Quality Control Methods for Medicinal Plant Materials. Geneva: WHO; 1996.

15. Mukherjee PK. Quality Control of Herbal Drugs: An Approach to Evaluation of Botanicals. $1^{\text {st }}$ ed. India: Publisher-Business Horizons; 2002. p. 113-9.

16. Paliwal P, Pancholi SS, Patel RK. Pharmacognostic parameters for evaluation of the rhizomes of Curcuma caesia. J Adv Pharm Technol Res 2011;2:56-61.

17. Andriyani R, Budiati TA, Pudjiraharti S. Effect of extraction method on total flavonoid, total phenolic content, antioxidant and anti-bacterial activity of Zingiberis officinale Rhizome. Procedia Chem 2015;16:149-54.

18. Phadungcharoen T, Theanphong O. Microscopic investigation of Curcuma petiolata roxb rhizome. BHST 2016;14:1-9.

Source of Support: Nil. Conflict of Interest: None declared. 